Ann. Anim. Sci., Vol. 12, No. 2 (2012) 237-245, DOI: 10.2478/v10220-012-0020-8

\title{
THE EXPRESSION OF BIRTH WEIGHT IS MODULATED BY THE BREEDING SEASON IN A GOAT MODEL
}

\author{
César A. Meza-Herrera ${ }^{1}$, Guadalupe Calderón-Leyva ${ }^{1}$, \\ Maria J. Soto-Sanchez ${ }^{1}$, José Abad-Zavaleta ${ }^{2}$, Juan M. Serradilla ${ }^{3}$, \\ Antón García-Martinez ${ }^{3}$, Rafael Rodriguez-Martinez ${ }^{4}$, \\ Francisco G. Veliz ${ }^{4}$, Ulises Macias-Cruz ${ }^{5}$, Homero Salinas-Gonzalez \\ ${ }^{1}$ Unidad Regional Universitaria de Zonas Áridas, Universidad Autónoma Chapingo, Bermejillo, \\ Durango, Mexico \\ ${ }^{2}$ Campus Loma Bonita, Universidad del Papaloapan, Oaxaca, Mexico \\ ${ }^{3}$ Departamento de Producción Animal, Universidad de Córdoba, Córdoba, Spain \\ ${ }^{4}$ Universidad Autónoma Agraria Antonio Narro, Torreón Coahuila, Mexico \\ ${ }^{5}$ Universidad Autónoma de Baja California, ICA, Mexico \\ ${ }^{6}$ Instituto Nacional de Investigaciones Forestales, Agrícolas y Pecuarias, Mexico \\ Corresponding author: cmeza2020@hotmail.com; cmeza2000@gmail.com
}

\begin{abstract}
Birth weight (BW) is frequently considered as an indicator to detect possible restrictions of intrauterine development. This study evaluated the effect of breeding season (BS) across year: spring (SP), summer (SM), fall (FL) and winter (WT) upon the expression of BW. This meta-analysis considered records $(n=1,084)$ collected from a commercial herd kept under intensive conditions $\left(22^{\circ} \mathrm{NL}, 1,835 \mathrm{~m}\right)$. The definitive statistical model for $\mathrm{BW}$ analysis considered the independent variables kidding year, (KY), genetic group (GT), litter size (LS), gender (GN), breeding season (BS), kidding season $(\mathrm{KS})$ plus the interactions $(\mathrm{KY} * \mathrm{GT})$ and $(\mathrm{GN} * \mathrm{BS})$. BW expression was affected $(P<0.05)$ by KY, GN, LS, KS, and KY*GT. Interestingly, while BW expression was not affected $(\mathrm{P}>0.05)$ by kidding season, it was affected $(\mathrm{P}<0.05)$ by breeding season. The highest and lowest $B W$ values were observed in $S P$ and $W N(3.34$ vs. $3.10 \mathrm{~kg} ; \mathrm{P}<0.05)$, respectively. This physiological scenario could be the result of embryonic-fetal adaptive responses representing homeostatic adaptations due to alterations including doe nutritional status, available quantity and quality of food to both the embryo and the fetus as well as to a changing external environment.
\end{abstract}

Key words: birth weight, breeding season, fetal growth and development, intrauterine environment

From a biological point of view in all mammal species, goats included, there is an optimal birth weight (BW) range within which normal physiological processes for growth and development can occur, reducing the expression of health dysfunctions 
while maximizing neonatal survival (Perez-Razo et al., 1998; Mellado et al., 2000). From a productive and economic viewpoint in small ruminants, BW expression is a key phenotypic characteristic of paramount importance in kid-milk goat production systems and their commercialization schemes (Meza-Herrera, 1986; Arechiga et al., 2008). Both fetal growth and development as well as BW expression are affected by genetic, placental and maternal cues (Meza-Herrera et al., 1987; Montaldo and Meza-Herrera, 1999; Xita and Tsatsoulis, 2010; Mellado et al., 2011).

While exposed to an accurate gestational environment, fetus is able to reach an adequate size according to its genetic potential. Nonetheless, perturbations at uterus level, either intrinsic or extrinsic in nature, may potentially compromise both growth and development of fetus, the BW expression as well as preweaning mortality (Meza-Herrera, 1986; Gonzalez-Bulnes et al., 2011). Prenatal development and final BW are both dependent upon a close relationship among the available nutritional level and the secretion pattern of diverse hormones and growth factors (Funston et al., 2010).

In addition, environmental fluctuations across year also determine different expressions on both BW and neonatal survival (Lincoln and Short, 1980). At the beginning of the embryonic life, although the embryo's nutritional requirements are low because of a low rate in the absolute growth, the rate of the relative growth is quite high. For this reason, several physiological, metabolic and genetic dysfunctions may occur, compromising the future development of the main organs and systems, a syndrome known as intrauterine growth retardation. Therefore, both the fetal and the birth weight relative to a gestational age, are frequently considered to measure and to detect intrauterine growth restriction (Wallace et al., 2005). In addition, experimental animal studies suggest that the nutritional, hormonal and metabolic environment afforded by the mother may permanently programme differentiating target tissues of the offspring toward the development of the metabolic syndrome in adult life (Xita and Tsatsoulis, 2010).

Such physiological scenario, which can be modified by environmental variations throughout the year, may not only compromise the neonatal health status but can also compromise fetal growth programming. Certainly, litters from mothers facing low nutrition levels during pregnancy show not only a decreased growth rate and low productivity, but can also significantly compromise their health status at preweaning stages (Schreurs et al., 2010) as well as their productive performance in adult life (Funston et al., 2010; Van der Liden et al., 2010; Xita and Tsatsoulis, 2010). The aim of this study was to evaluate the influence of some environmental factors and more specifically the breeding season upon the expression of birth weight considering the goat as an animal model.

\section{Material and methods}

The study was carried out at the Center for Goat Breeding, in the state of San Luis Potosí, Mexico, located at $22^{\circ} 12^{\prime} \mathrm{NL}$ and $100^{\circ} 55^{\prime} \mathrm{WL}$, at an altitude of $1,835 \mathrm{~m}$, 
and annual averages for precipitation and temperature of $271 \mathrm{~mm}$ and $17^{\circ} \mathrm{C}$, respectively. The Center initiated activities in 1993, importing 10 Boer bucks from New Zealand, a set of 10 Boer females from the USA, and an elite herd of 230 Nubian females. Does had free access to a mixed diet composed of alfalfa hay [ $14 \%$ crude protein (CP), 4.7 net energy for maintenance (NEm MJ kg-1)], corn silage $(8.1 \%$ $\left.\mathrm{CP}, 6.7 \mathrm{NEm} \mathrm{MJ} \mathrm{kg}{ }^{-1}\right)$ and corn grain $\left(11.2 \% \mathrm{CP}, 9.9 \mathrm{NEm} \mathrm{MJ} \mathrm{kg} \mathrm{Ng}^{-1}\right)$, mineral salts, fresh water, and shades. Diets were balanced to cover $120 \%$ of their nutritional requirements according to physiological stage and gender (NRC, 1981). Animals were kept under stall-fed conditions with an uncovered area of 6-10 $\mathrm{m}^{2}$ per animal and were physically allocated according to their physiological stage, gender and genotype.

Regarding the newborn kids, the umbilical cord was cut and disinfected at birth and kids had direct access to colostrum from their mother. All kids were individually identified while recording the information on gender, birth date, birth weight, doe and buck identification number, and genetic group. On day 15 after birth, kids were vaccinated against Clostridium and Pasteurella, received vitamins A, D and E (i.m.) and were treated against internal and external parasites. All the management and practices in this study were done in accordance with accepted international guidelines (FASS, 1999).

Birth weight was evaluated considering an ANOVA for unbalanced data in a completely random design. The original model to analyse BW included the independent variables: gender (GD, male, female), genotype (GT, Boer, 1/2 Boer 1/2 Nubian, 3/4 Boer 1/4 Nubian, 7/8 Boer 1/8 Nubian), litter size (LS, simple, twins, triplets and quadruplets), breeding season (BS, spring-SP, summer-SM, fall-FL and winter-WT), kidding season (KS, spring-SP, summer-SM, fall-FL and winter-WT) and year of birth (KY, 1995, 1995, 1996 1998, 1999 and 2000) as well as first-order interactions. In the event of significant differences among variables, mean separation considered the LSMEANS-PDIFF option of the PROC GLM. All the statistical analyses were computed using the GLM procedures of SAS (SAS Inst. Inc., Cary, $\mathrm{NC}$, USA). While reported values are defined as least-square means \pm standard error, the most conservative SE is presented.

\section{Results}

The once carried-out original model included all the main effects as well as firstorder interactions, and a second model included only those variables and their interactions declared as significant upon BW expression, including KY, GT, LS, GD, $\mathrm{BS}, \mathrm{KS}, \mathrm{KY}^{*} \mathrm{GT}$ and $\mathrm{GD}^{*} \mathrm{BS}$. Thereafter, the definitive model included those variables which affected $(\mathrm{P}<0.001)$ the BW expression: KY, GT, LS, BS and KY*GT $\left(\mathrm{R}^{2}=39.56 \%\right.$ and $\mathrm{CV}=19.60 \%$; Tables 1,2 and 3$)$.

The overall average for BW was $3.18 \mathrm{~kg}$; both KY and GT affected $(\mathrm{P}<0.001)$ BW expression, observing the highest BW in 1995 (3.73 kg) while the lowest $(2.72$ $\mathrm{kg}$ ) in 1998 , with an average value for the six years of study of $3.23 \mathrm{~kg}$. The GT $1 / 2$ 
Boer represented the largest BW $(3.65 \mathrm{~kg})$, while the lowest BW was observed in the Boer genotype $(2.63 \mathrm{~kg})$; the greater the percentage of Boer genes, the lower the BW. Also, the KY*GT interaction affected $(\mathrm{P}<0.05) \mathrm{BW}$ (Tables 1 and 2). LS also affected $(\mathrm{P}<0.001) \mathrm{BW}$; while singles had the largest $\mathrm{BW}(3.44 \mathrm{~kg})$, the lowest BW occurred in triplets $(2.85 \mathrm{~kg})$, without differences $(\mathrm{P}>0.05)$ between triplets and quadruplets (Table 1). Interestingly, while kidding season did not affect BW, BS had an effect $(\mathrm{P}<0.001)$ on the expression of $\mathrm{BW}$; kids born from does bred in SP represented the largest BW, followed by FL without differences between these two seasons, while the WT represented the lowest BW (Table 3).

Table 1. Least-square means \pm standard error for birth weight $(\mathrm{BW}, \mathrm{kg})$ according to year of birth and goat genotype in Boer and Boer $\times$ Nubian kids

\begin{tabular}{l|c|c|c}
\hline \multicolumn{1}{c|}{ Variables } & $\mathrm{N}$ & $\mathrm{BW}(\mathrm{kg})$ & $\mathrm{SE}$ \\
\hline Year of birth & & & \\
1994 & 49 & $3.33 \mathrm{~b}$ & 0.49 \\
1995 & 289 & $3.73 \mathrm{a}$ & 0.79 \\
1996 & 171 & $3.34 \mathrm{~b}$ & 0.59 \\
1998 & 341 & $2.72 \mathrm{~d}$ & 0.61 \\
1999 & 143 & $3.01 \mathrm{c}$ & 0.69 \\
2000 & 91 & $3.02 \mathrm{c}$ & 0.82 \\
Genotype & $\mathrm{N}$ & $\mathrm{BW}(\mathrm{kg})$ & S.E. \\
$1 / 2$ Boer 1/2 Nubian & 407 & $3.65 \mathrm{a}$ & 0.73 \\
3/4 Boer 1/4 Nubian & 435 & $3.01 \mathrm{~b}$ & 0.68 \\
$7 / 8$ Boer 1/8 Nubian & 182 & $2.71 \mathrm{c}$ & 0.65 \\
Boer & 60 & $2.63 \mathrm{c}$ & 0.63 \\
\hline
\end{tabular}

a, b, c, d-Values with different letters within column and main effect, differ $(\mathrm{P}<0.05)$.

$\mathrm{SE}=$ Standard error.

Table 2. Least-square means \pm standard error for birth weight $(\mathrm{BW}, \mathrm{kg})$ according to year of birth and goat genotype in Boer and Boer $\times$ Nubian kids

\begin{tabular}{ll|l|l|l}
\hline $\begin{array}{c}\text { Year of birth/ } \\
\text { Genotype }\end{array}$ & $\begin{array}{c}1 / 2 \text { Boer } \\
1 / 2 \text { Nubian }\end{array}$ & $\begin{array}{c}3 / 4 \text { Boer } \\
1 / 4 \text { Nubian }\end{array}$ & $\begin{array}{c}7 / 8 \text { Boer } \\
1 / 8 \text { Nubian }\end{array}$ & Boer \\
\hline 1994 & $3.33 \mathrm{bcd}$ & & $2.82 \mathrm{def}$ \\
1995 & $3.77 \mathrm{~b}$ & & \\
1996 & $3.42 \mathrm{bc}$ & $3.27 \mathrm{bcd}$ & $2.49 \mathrm{f}$ \\
1998 & $4.40 \mathrm{a}$ & $2.82 \mathrm{f}$ & $2.44 \mathrm{def}$ & $2.69 \mathrm{cdef}$ \\
1999 & & $3.38 \mathrm{ef}$ & $2.96 \mathrm{bcd}$ & \\
2000 & & $3.13 \mathrm{cde}$ & $2.70 \mathrm{ef}$ & \\
\hline
\end{tabular}

a, b, c, d-Values with different letters within column and main effect, differ $(\mathrm{P}<0.05)$. 
Table 3. Least-square means \pm standard error for birth weight $(\mathrm{BW}, \mathrm{kg})$ according to litter size and breeding season in Boer and Boer $\times$ Nubian kids

\begin{tabular}{l|c|c|c}
\hline \multicolumn{1}{c|}{ Variables } & $\mathrm{N}$ & $\mathrm{BW}(\mathrm{kg})$ & SE \\
\hline Litter size & \multicolumn{3}{c}{} \\
$\quad$ Singles & 207 & $3.44 \mathrm{a}$ & 0.85 \\
Twins & 665 & $3.20 \mathrm{~b}$ & 0.75 \\
Triplets & 185 & $2.85 \mathrm{c}$ & 0.73 \\
Quadruplets & 27 & $2.91 \mathrm{c}$ & 0.73 \\
Breeding season & & & \\
Spring & 85 & $3.34 \mathrm{a}$ & 0.59 \\
Summer & 720 & $3.16 \mathrm{~b}$ & 0.68 \\
Fall & 203 & $3.22 \mathrm{ab}$ & 0.68 \\
Winter & 76 & $3.10 \mathrm{~b}$ & 0.73 \\
\hline
\end{tabular}

a, b, c, d - Values with different letters within column and main effect, differ $(\mathrm{P}<0.05)$.

$\mathrm{SE}=$ Standard error.

\section{Discussion}

The hypothesis proposed at the beginning of the study stated differences for the BW of kids born from does bred in different seasons throughout the year (SP, SM, FL and WT), since at least one breeding season should differ from the others with respect to the BW expression; such hypothesis is accepted. Several studies in different ruminant species, and particularly in goats, have demonstrated the influence of diverse fixed effects upon BW, including gender, litter size, year of birth, season of birth, age of mother, parity number and goat genotype among others (Meza-Herrera, 1986; Meza-Herrera et al., 1987; Montaldo and Meza-Herrera, 1999). Nonetheless, the evaluation of the effect of breeding season upon birth weight expression in goats is really scarce. Therefore, the discussion of our results will mainly be addressed to emphasize some physiological considerations regarding the effect that BS may have upon the success of the organogenesis process. Certainly, in our database, BS was defined as the most proximal environmental factor affecting organogenesis, which in turn may negatively affect the expression of BW, and consequently, potentially influence in a negative fashion productive, reproductive and health outcomes in adult life.

Mammals perceive different external cues in order to anticipate and to exert compensatory responses to face different environmental conditions throughout the year. In this way, animals may accumulate body fat or grow their hair coats according to each season (Meza-Herrera et al., 2007). In other species, seasonal reproduction determines the most adequate time for reproduction in order to give birth to litters in the best possible season of the year (Gonzalez-Bulnes et al., 2011). This evolutionary approach is exerted in order to align their reproductive outcome to the most favourable environmental conditions regarding temperature and food availability as well as to assure the best conditions for growth and development of their offspring (Lincoln, 1992). 
According to Bronson and Heideman (1994), seasonal breeding is regulated by a complex relationship among physical factors such as photoperiod, food availability, socio-sexual interactions, as well as other management practices. All of these factors exert a close connection to define the phenotypic expression of $\mathrm{BW}$, and as previously mentioned, the combined effect of these factors may promote fetal growth retardation affecting not only BW but also fetal programming, which in turn may affect both productive and reproductive outcomes in adult life (Xita and Tsatsoulis, 2010).

There are many situations in which the environment plays a critical role in the health status of an individual, but none is more important than those the embryo face, particularly at the time of organogenesis. This last process will significantly influence not only fetal and neonatal performance, but also metabolic and physiological outcomes in adult life (Doyle and Andersen, 2010; Xita and Tsatsoulis, 2010). One such environmental cue that highly affects embryonic and fetal growth is the nutritional level of the mother during conception and pregnancy (Warner and Ozanne et al., 2010).

During both the dry and cold seasons, forage and feedstuff quality is frequently decreased being inadequate for the high nutritional demands observed during growth, gestation and lactation; all of them are physiological processes that demand high quality supplements regarding protein and energy content (Fontaneli et al., 2005). Once pregnancy is established, a suboptimal nutritional status or maternal premature malnutrition, along with restricted food consumption, may negatively affect both growth and development at either the embryonic or the fetal stages (Vinsky et al., 2006).

Without doubt, fetal growth retardation promotes a decreased BW as well as a decreased number of myofibres, a physiological scenario that may not be compensated during postnatal stages. Pigs with reduced BW show the lowest growth rates, high fat deposition and poorest meat quality. The number of prenatally formed muscular fibres is positively correlated to BW, and denotes a significant role in the relationship between increased BW and meat quality (Rehfeldt and Kuhn, 2006). The metabolic consequences of exposing mothers to a decreased protein supplementation in early gestation may promote fetal stress, which may induce metabolic disorders in adult life (Erhuma et al., 2007). Undoubtedly, disturbances in the supply of oxygen and nutrients to the fetus during early pregnancy, when the embryonic nutritional requirements are yet minimal, may not only promote adverse fetal growth patterns, but also is associated with the development of the metabolic syndrome, and may also compromise not only ulterior development but also competence of either the endocrine or the vascular system in adult life (Doyle and Andersen, 2010; Warner et al., 2010; Xita and Tsatsoulis, 2010). Certainly, with the advent of modern perinatal and neonatal intensive care, most survivors of extreme prematurity which have as a common link a reduced BW, have higher rates of adverse health scenarios such as nutritional, cardiovascular, respiratory, motor, cognitive, psychiatric and functional outcomes in adulthood (Doyle and Andersen, 2010).

A possible pathway through which BS could affect BW, may consider the following: environmental factors across the year determine quality and quantity of food 
resources, influencing oocyte quality, both growth and development at the onset of embryonic life and organogenesis may also be affected, while uterine capacity, and, in turn, size, architecture and function of placenta could be also compromised; all of them may affect organogenesis, fetal growth and birth weight.

In conclusion, the highest BW was shown by those kids whose dams were bred during spring, while the lowest BW occurred in kids whose dams were bred in winter. This physiological scenario could be the result of embryonic-fetal adaptive responses representing homeostatic adaptations due to alterations including doe nutritional status, organogenesis, available quantity and quality of food to both the embryo and the fetus as well as a changing external environment. Further studies addressing physiological and productive scanning of the offspring designed to evaluate productive and reproductive performance in the adult life, are warranted.

\section{Acknowledgments}

This study was carried out within the outlined actions of the International Collaborative Projects "CONACYT-FOMIX-DURANGO, DGO-2008-C01-87559 \& CONACYT-DGO-2009-C02-116746", funded by the National Council of Science and Technology, Mexico, as well as "ALFA-III-ALAS, DCI-ALA/A9.09.01 /08/19189/161-358/ALFA-III-82, supported by the European Union. The authors acknowledge financial support from these Projects.

\section{References}

Arechiga C.F., Aguilera J.I., Rincón R.M., Mendez de Lara S., Bañuelos V.R., M e z a - H e rrer a C.A. (2008). Role and perspectives of goat production in a global world, Trop. Subtrop. Agroecosys., 9: 1-14.

B ron s on F.H., He ideman P.D. (1994). Seasonal regulation of reproduction in mammals. In: The physiology of reproduction, Knobil E., Neill J.D. (eds). Raven Press, Ltd. New York, 2nd ed., pp. 541-583.

D o y le L.W., A nders on P.J. (2010). Adult outcome of extremely preterm infants. Pediatrics, 126: $342-351$.

Erhuma A., S alter M.A., S culley D.V., Langley-Evans S.C., B en net t A. (2007). Prenatal exposure to a low protein diet programmes disordered regulation of lipid metabolism in the ageing rat. Am. J. Physiol. Endocrinol. Metab., 292: E1702-E1714.

Fontaneli R.S., S ollenberger L.E., Littell R.C., S taples C.R. (2005). Performance of lactating dairy cows managed on pasture-based or in freestall barn-feeding systems. J. Dairy Sci., 88: $1264-1276$.

Funston R.N., Lars on D.M., V onnahme K.A. (2010). Effects of maternal nutrition on conceptus growth and offspring performance: implications for beef cattle production. J. Anim. Sci., 88 (13 Suppl): E205-E215.

Gonzalez-Bulnes A., Meza-Herrera C.A., Rekik M., B en Salem H., Kridli R.T. (2011). Limiting factors and strategies for improving reproductive outputs of small ruminants reared in semi-arid environments. In: Semi-arid environments: Agriculture, water supply and vegetation, Degenovine K.M. (ed.). Nova Science Publishers Inc. Hauppauge, NY, USA, pp. 41-60.

L inc oln G.A. (1992). Photoperiod-pineal-hypothalamic relay in sheep. Anim. Reprod. Sci., 28: 203-217.

L in c oln G.A., S h ort R.V. (1980). Seasonal breeding: Nature's contraceptive. Rec. Prog. Horm. Res., 36: 1-52.

Mellad o M., Vera T., Meza-Herrera C.A., Ruiz F. (2000). A note on the effect of air temperature during gestation on birth weight and neonatal mortality of kids. J. Agric. Sci., 135: 91-94. 
Mellado M., Meza-Herrera C.A., Arevalo J.R., De Santiago-Miramontes M., Rodriguez A., Luna-Orosco J.R., Veliz-Deras F.G. (2011). Relationship between litter birth weight and litter size in five goat genotypes. Anim. Prod. Sci., 51: 144-149.

Meza-Herrera C.A. (1986). Genetic resources for production in five goat breeds in northern Mexico. M.Sc. Thesis. Faculty of Higher Studies-Cuautitlán, National Autonomous University of Mexico, Mexico, 86 pp.

Meza-Herrera C.A., S a n chez F., Torres-Hernandez G. (1987). Genetic and environmental factors affecting preweaning traits in goats. I. Breed and environmental factors affecting birth weight, one month weight and average daily gain. Proc. IV International Congress on Goats, 14-19.07.1987, Brasilia, Brazil, pp. 1320-1321.

Meza-Her rera C.A., B o c a n e gra J.A., B a ñ u lo s V.R., A r e c hi g a C.F., R in cón R.M., Ochoa-Cordero M.A., Juarez-Reyes A.S., Cerrillo-S oto M.A., Salinas H. (2007). Circannual fluctuations in serum cortisol and glucose concentrations and hair coat growth in goats. J. Appl. Anim. Res., 31: 79-82.

Montaldo H., Meza-Herrera C.A. (1999). Genetic goat resources in Mexico: Bio-economical efficiency of local and specialized genotypes. Wool Tech. Sheep Breed, 47: 184-198.

NRC (1998). Nutrient requirements of goats: Angora, dairy and meat goats in temperate and tropical countries. National Academy Press, Washington, DC, USA, pp. 1-91.

Pér e z-R a zo M.A., S á n chez F., M e z a - H e r rera C.A. (1998). Factors affecting kid survival in five goat breeds. Canadian J. Anim. Sci., 78: 407-411.

R e h feld t C., Kuhn G. (2006). Consequences of birth weight for postnatal growth performance and carcass quality in pigs as related to myogenesis. J. Anim. Sci., 84 (Suppl.): E113-E123.

Schreurs N.M., Kenyon P.R., Mulvanev F.J., Morel P.C.H., W es t D.M., Morris S.T. (2010). Effect of birth weight and birth rank on the survival of single and twin lambs born to ewe lambs. Anim. Prod. Sci., 50: 460-464.

Van de Liden D., Kenyon P., Blair H., Lopez-Villalobos N., Jenkinson C., Peterson A., Mackensie D. (2010). Effect of ewe size and nutrition during pregnancy on glucose metabolism, fat metabolism and adrenal function of post-pubertal female offspring. Anim. Prod. Sci., 50: 869-879.

Vinsky M.D., Novak S., Dix on W.T., D y ck M.K., F ox croft G.R. (2006). Nutritional restriction in lactating primiparous sows selectively affects female embryo survival and overall litter development. Reprod. Fertil. Dev., 18: 347-355.

W a 11 a c e J.M., Miln e J.S., A it ke n R.P. (2005). The effect of overnourishing singleton bearing adult ewes on nutrient partitioning to the gravid uterus. Br. J. Nutr., 94: 533-539.

Warner M.J., Ozanne S.E. (2010). Mechanisms involved in the developmental programming of adulthood disease. Biochem. J., 427: 333-347.

Xit a N., Ts at s oulis A. (2010). Fetal origins of the metabolic syndrome. Ann. N.Y. Acad. Sci., 1205: 148-155.

Accepted for printing 8 XII 2011

CÉSAR A. MEZA-HERRERA, GUADALUPE CALDERÓN-LEYVA, MARIA J. SOTO-SANCHEZ, JOSÉ ABAD-ZAVALETA, JUAN M. SERRADILLA, ANTÓN GARCÍA-MARTINEZ, RAFAEL RODRIGUEZ-MARTINEZ, FRANCISCO G. VELIZ, ULISES MACIAS-CRUZ, HOMERO SALINAS-GONZALEZ

\title{
Wpływ sezonu rozpłodowego na ekspresję urodzeniowej masy ciała w modelu kozim
}

\author{
STRESZCZENIE
}

Masa ciała przy urodzeniu (BW) często służy jako wskaźnik do wykrywania możliwych ograniczeń w wewnątrzmacicznym rozwoju płodu. W badaniach tych oceniano wpływ sezonu rozpłodowego (BS) 
w ciągu roku: wiosna (SP), lato (SM), jesień (FL), zima (WT) na ekspresję BW. W metaanalizie wzięto pod uwagę dane $(\mathrm{n}=1084)$ zebrane $\mathrm{z}$ komercyjnego stada utrzymywanego $\mathrm{w}$ intensywnych warunkach ( $22^{\circ}$ szer. geogr. półn., 1835 m n.p.m.). Ostateczny model statystyczny dla analizy BW uwzględniał następujące zmienne niezależne: rok wykotu $(\mathrm{KY})$, grupę genetyczną $(\mathrm{GT})$, wielkość miotu (LS), płeć (GN), sezon rozpłodowy (BS), sezon wykotów (KS) z interakcjami (KY*GT) i (GN*BS). Na ekspresję BW $(\mathrm{P}<0,05)$ wpłynęły KY, GN, LS, KS i KY*GT. Co ciekawe, na ekspresję BW $(\mathrm{P}>0,05)$ wpływał nie sezon wykotów, lecz sezon rozpłodowy $(\mathrm{P}<0,05)$. Najwyższe i najniższe wartości $\mathrm{BW}$ zaobserwowano na wiosnę i w zimie $(3,34$ vs. $3,10 \mathrm{~kg} ; \mathrm{P}<0,05)$. Ten fizjologiczny scenariusz mógł być rezultatem odpowiedzi adaptacyjnych zarodka/płodu, będących homeostatycznymi adaptacjami spowodowanymi zmianami w stanie odżywienia samicy, ilości i jakości pożywienia dostępnego zarówno dla zarodka, jak i płodu oraz zmiennym środowiskiem zewnętrznym. 